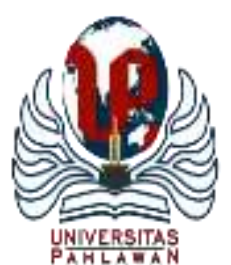

Edukatif : Jurnal Ilmu Pendidikan Volume 3 Nomor 5 Tahun 2021 Halm 3361 - 3370

EDUKATIF: JURNAL ILMU PENDIDIKAN

Research \& Learning in Education

https://edukatif.org/index.php/edukatif/index

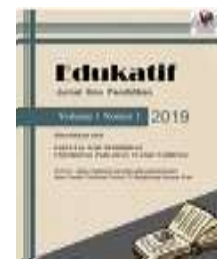

\title{
Penerapan Bimbingan Konseling Berbasis Buku Poin dalam Membina Kedisiplinan Peserta Didik di Madrasah Aliyah
}

\author{
Ainur Raman ${ }^{1 凶}$, Begjo Tohari $^{2}$ \\ Universitas Islam Negeri Sunan Kalijaga Yogyakarta, Indonesia ${ }^{1,2}$ \\ E-mail : hainurrahman94@gmail.com ${ }^{1}$, toharibegjo@ gmail.com ${ }^{2}$
}

\begin{abstract}
Abstrak
MAN 1 Tegal merupakan madrasah yang sangat melekat dengan pendidikan agamanya, karena lingkungan yang berdekatan dengan pondok pesantren. Pada dasarnya pondok pesantren selalu menerapkan peraturanperaturan dengan menekankan pada tingkat kedisiplinan yang tinggi. Penelitian ini bertujuan untuk mengetahui bagaimana penerapan bimbingan konseling berbasis buku poin dalam membina kedisiplinan peserta didik di MAN 1 Tegal, Sekolah ini mulai menerapkan kredit poin pelanggaran (KPP) pada tahun 2007, sebelumnya hanya diterapkan peraturan atau tata tertib biasa. Metode yang digunakan dalam penelitian ini yaitu berupa metode penelitian kualitatif dan menggunakan penelitian deskriptif. Metode kualitatif adalah metode yang lebih menekankan kepada aspek pemahaman secara mendalam kepada suatu permasalahan. Adapun yang menjadi sumber data dalam penelitian ini adalah kepala Bimbingan Konseling, dan Waka Kesiswaan MAN 1 Tegal, dengan menggunakan metode observasi, wawancara dan dokumentasi. Adapun hasil buku poin yang di terapkan adalah sebagai tata tertib MAN 1 Tegal yang memiliki sifat lebih mengikat di setiap individu peserta didik karena berbentuk buku dan di setiap peserta didik mempunyai buku poin sebagai catatan kepribadiannya.
\end{abstract}

Kata Kunci : Bimbingan Konseling, Buku Poin, Kedisiplinan.

\begin{abstract}
MAN I Tegal is a madrasa that is closely related to its religious education, because of its proximity to the Islamic boarding school. Basically, Islamic boarding schools always apply regulations by emphasizing a high level of discipline. This study aims to determine how the application of point book based counseling guidance in fostering student discipline in MAN 1 Tegal. This school began implementing credit poin violations (KKP) in 2007, previously only applied rules or regular rules. The method used in this research is in the form of qualitative research methods and uses descriptive research. Qualitative methods are methods that emphasize in depth understanding aspects of a problem. As for the source of data in this study is the head of counseling guindance, and student time in MAN 1 Tegal, using the method of observation, interview and documentation. The results of the point book that are applied are as the rules of MAN 1 Tegal which have a more binding nature in each individual student because it is in the from of book and in each student has a point book as a record of his personality.
\end{abstract}

Keywords: Counseling Guidance, Points Book, Discipline.

Copyright (c) 2021 Ainur Raman, Begjo Tohari

$\triangle$ Corresponding author

Email : hainurrahman94@ gmail.com

DOI : https://doi.org/10.31004/edukatif.v3i5.457

ISSN 2656-8063 (Media Cetak)

ISSN 2656-8071 (Media Online)

Edukatif : Jurnal Ilmu Pendidikan Vol 3 No 5 Tahun 2021 p-ISSN 2656-8063 e-ISSN 2656-8071 


\section{Penerapan Bimbingan Konseling Berbasis Buku Poin dalam Membina Kedisiplinan Peserta Didik di}

Madrasah Aliyah - Ainur Raman, Begjo Tohari

DOI: https://doi.org/10.31004/edukatif.v3i5.457

\section{PENDAHULUAN}

Pendidikan merupakan salah satu cara untuk membentuk sikap atau pribadi peserta didik menjadi lebih baik. Pendidikan berkenaan dengan perkembangan dan perubahan kelakuan anak didik. Pendidikan bertalian dengan transmisi pengetahuan, sikap, kepercayaan, keterampilan, dan aspek-aspek kelakuan lainnya pada generasi muda (Nasution, 2010). Pendidikan adalah suatu yang urgen yang pada awalnya memperoleh sebuah prioritas utama dalam kepedulian public (Muthoharoh \& Sakti, 2021).

Sekolah merupakan lembaga pendidikan yang menjadi wadah bagi peserta didik untuk mengembangkan potensinya dan membentuk kepribadian yang lebih baik. Sekolah memang bukan satu-satunya lingkungan tempat anak memperoleh pendidikan, karena pendidikan juga dapat diperoleh dari lingkungan masyarakat. Pendidikan berkenaan dengan perkembangan dan perubahan kelakuan anak didik. Pendidikan bertalian dengan transmisi pengetahuan, sikap, kepercayaan, ketrampilan dan aspek-aspek kelakuan lainnya kepada generasi muda. Pendidikan merupakan proses mengajar dan belajar pola-pola kelakuan manusia menurut apa yang diharapkan oleh masyarakat (Nasution, 2010).

Dalam UU Sisdiknas No. 20 tahun 2003, pendidikan ialah usaha sadar dan terencana untuk mewujudkan suasana belajar dan proses pembelajaran supaya peserta didik secara aktif untuk meningkatkan potensi dirinya supaya mempunyai kepribadian, kecerdasan, akhlak mulia serta keterampilan yang dibutukan dirinya dan masyarakat (Suhaeni, 2018). Dalam hukum Islam untuk memperoleh kejayaan belajar, etika wajib diikutsertakan pada saat kegiatan interaksi di dalam belajar dan mengajar berlangsung. Dalam ranah belajar dan mengajar dalam pandangan Islam,etika ialah moral yang bersumber dari al-qur'an dan Sunnah (Rasimin et al., 2021).

Sekolah diharapkan bisa memberikan sebuah sarana dan prasarana yang mendukung terhadap guru dan peserta didik sehingga kegiatan belajar mengajar berjalan dengan optimal (Diana \& Pambudi, 2013). Pelaksanaan program dapat berjalan dengan baik apabila ketika dalam penyusunan dan pelaksanaannya dikelola dengan baik juga, karena pada dasarnya setiap aktifitas atau kegiatan selalu mempunyai tujuan yang ingin dicapai (Hasibuan, 2015).

UU No. 192007 tentang Standart Pengelolaan Pendidikan bahwasanya sekolah atau madrasah diharuskan menetapkan panduan tata tertib untuk mewujudkan suasana, iklim serta lingkungan pendidikan yang kondusif (Desiyanto et al., 2018). Dalam menjalankan kedisiplinan sekolah tidak ditekankan terhadap satu pihak saja, tetapi untuk menjalankannya sebisa mungkin dikerjakan oleh semua elemen yang berada di lingkungan sekolah (Fitriawati et al., 2017). Disiplin peserta didik ialah sebuah kondisi yang mana penampilan, sikap serta perilaku peserta didik sejalan dengan tatanan nilai, norma dan peraturan yang berlaku di lembaga sekolah (Hidayati et al., 2020). Aturan atau nilai dan norma di setiap sekolah sering kali berbeda, karena visi dan misi setiap sekolah tidak semuanya sama, seperti di MAN 1 Tegal menerapkan aturan sistem kredit poin pelanggaran (KPP) atau biasa disebut buku poin. Beberapa sekolah sudah ada yang menerapkan aturan tersebut akan tetapi banyak juga yang hanya berhenti di jalan, karena tidak dikelola dengan baik.

Kedisiplinan merupakan sebuah kekuatan yang megharuskan peserta didik dalam mentaati peraturan. Perilaku disiplin mengajarkan anak didik dalam memilih mana yang boleh dikerjakan dan tidak boleh dikerjakan (Adianto et al., 2020). Perilaku disiplin adalah hal yang urgen yang wajib diberikan terhadap peserta didik. Disiplin berarti mematuhi dan mentaati apa yang sudah menjadi kesepakatan (Supiana et al., 2019). (Rasdiyanah, 2005), mengemukakan disiplin ialah ketundukan untuk menghargai dan melakukan sebuah sistem yang mengharuskan seseorang untuk patuh terhadap keputusan, perintah atau ketetapan yang berlaku. Dengan bahasa lain, disiplin ialah kepatuhan menghormati ketentuan serta peraturan yang sudah ditetapkan (Hadianti, 2008).

Madrasah Aliyah Negeri 1 Tegal merupakan madrasah yang sangat melekat dengan pendidikan agamanya, karena lingkungan yang berdekatan dengan pondok pesantren. Pada dasarnya pondok pesantren selalu menerapkan peraturan-peraturan dengan menekankan pada tingkat kedisiplinan yang tinggi, akan tetapi 


\section{Penerapan Bimbingan Konseling Berbasis Buku Poin dalam Membina Kedisiplinan Peserta Didik di Madrasah Aliyah - Ainur Raman, Begjo Tohari}

DOI: https://doi.org/10.31004/edukatif.v3i5.457

di Man 1 Tegal tidak semuanya bertempat tinggal di pondok pesantren, melainkan ada juga yang bertempat tinggal bersama orang tua di rumah (laju), hal tersebut mengindikasikan bahwa tingkat perilaku menyimpang dan kedisiplinan masing-masing peserta didik berbeda-beda, sehingga sekolah menerapkan norma-norma yang mengatur perilaku peserta didiknya, tetapi masih banyak juga terjadi pelanggaran-pelanggaran yang dilakukan peserta didik yang relatif sulit untuk dikendalikan oleh tenaga pendidik, realitas umum memperlihatkan bahwa masih banyak siswa-siswi sekolah yang melanggar aturan, mulai dari pelanggaran dengan skala kecil sebut saja peserta didik yang merokok, bolos, hingga pelanggaran dengan skala yang besar seperti tawuran antar pelajar, dan sebagainya.

Berdasarkan hasil observasi, sekolah ini mulai menerapkan KPP pada tahun 2007, sebelumnya hanya diterapkan peraturan atau tata tertib biasa. Di MAN 1 Tegal KPP ini lebih dikenal dengan nama Buku Poin. Buku poin yang diterapkan di MAN Babakan ini merupakan suatu terobosan baru dalam mendisiplinkan peserta didik, dimana sebelum buku poin diterapkan tingkat indisipliner atau pelanggaran yang dilakukan peserta didik MAN 1 Tegal semakin lama semakin meningkat. Sehingga perlu adanya sebuah kajian mendalam tentang pengelolaan program tersebut mulai dari perencanaan, pelaksanaan, pengawasan dan evaluasi agar program tersebut dapat berjalan dengan baik.

\section{METODE PENELITIAN}

Penelitian ini merupakan penelitian yang menggunakan metode penelitian kualitatif. Dimana penelitian kualitatif merupakan penelitian yang menghasilkan prosedur analisis yang tidak menggunakan prosedur analisis statistik atau cara kuantitatif lainnya. Penelitian kualitatif berupaya untuk menyajikan dunia sosial dan perspektifnya di dalam dunia, dari segi konsep, perilaku, persepsi dan persoalan tentang manusia yang di teliti (Sugiyono, 2011). Pemilihan metode kualitatif ini didasarkan pada kelebihan metode penelitian kualitatif seperti data yang diperoleh lebih dalam serta mempertimbangkan relevansi dengan fokus masalah yang dikaji sehingga lebih tepat jika menggunakan metode penelitian kualitatif.

Peneliti menggunakan metode penelitian kualitatif dengan tujuan hasil dari penelitian ini dapat diuraikan menggunakan deskripsi berupa kalimat sesuai dengan fokus permasalahan. Metode kualitatif ini dipandang sesuai dengan permasalahan yang dikaji dalam penelitian ini, yaitu mengkaji suatu fenomena berdasarkan perilaku atau tindakan, dan meneliti sesuatu dari segi prosesnya (Sukmadinata, 2011). Hal ini kaitannya dengan pengelolaan buku poin di MAN 1 Tegal dalam upaya meningkatkan kedisiplinan peserta didik.

Adapun jenis dan sumber data yang digunakan dalam penelitian ini adalah data kualitatif, yaitu data yang disajikan dalam bentuk kata verbal bukan dalam bentuk angka. Sumber data dalam penelitian ini adalah subjek dari mana data dapat diperoleh. Adapun yang menjadi sumber data dalam penelitian ini adalah kepala sekolah, waka kesiswaan, waka kurikulum, guru BK, dan wali kelas MAN 1 Tegal, menggunakan metode wawancara, observasi dan dokumentasi.

\section{HASIL DAN PEMBAHASAN}

\section{Gambaran Umum Madrasah Aliyah Negeri 1 Tegal (MAN 1 Tegal)}

Madrasah Aliyah Negeri 1 Tegal merupakan sekolah yang berada di Dusun Babakan, Desa Jatimulya Kecamatan Lebaksiu Kabupaten Tegal. Sekolah ini berada di atas tanah seluas 9.200 M2. Lokasi MAN 1 Tegal tergolong cukup strategis dan kondusif untuk belajar, karena berada sekitar 1,5 Kilometer (KM) dari jalan raya poros penghubung Tegal-Purwokerto. Sebagai sekolah dengan nuansa agamis, Madrasah Aliyah Negeri 1 Tegal memiliki perbedaan dengan sekolah umum lainnya seperti SMA atau SMK, karena terdapat mata pelajaran tertentu yang berkaitan dengan agama Islam seperti mata pelajaran Qur'an Hadits, Akidah 


\section{Penerapan Bimbingan Konseling Berbasis Buku Poin dalam Membina Kedisiplinan Peserta Didik di}

Madrasah Aliyah - Ainur Raman, Begjo Tohari

DOI: https://doi.org/10.31004/edukatif.v3i5.457

Akhlak, Fiqh, Bahasa Arab, dan Baca Tulis Al-Qur'an (BTA). Selain itu, terdapat pula program-program tambahan serta jurusan tambahan, yaitu program seperti kegiatan Istighosah, pesantren kilat, kajian kitab Ta'limul Muta'allim dan Qiro'atul Qutub yang terjelma dalam sebuah mata pelajaran, ekstrakurikuler keagamaan serta memiliki jurusan tambahan yaitu jurusan Agama (selain jurusan regular IPA dan IPS) yang biasanya tidak ditemui di sekolah umum yang lain (Administrator, 2019).

Peserta didik MAN Babakan berjumlah 1.338 siswa dengan rincian sekitar 50\% santri dan 50\% non santri. Santri yang dimaksud yaitu santri yang berasal dari Pondok Pesantren (Pon-Pes) Ma'hadut Tholabah yang juga berada di Babakan, banyaknya santri yang menjadi siswa MAN Babakan ini tidak lepas dari ikatan historis MAN 1 Tegal yang merupakan bagian dari Yayasan Pondok Pesantren Ma'hadut Tholabah. Banyaknya jumlah peserta didik MAN 1 Tegal yang juga menjadi santri pondok pesantren ini menjadikan nuansa agamis sekolah lebih kental. Tak terkeculai yaitu tata tertib yang diterapkan MAN 1 Tegal yang berisi peraturan-peraturan yang sesuai dengan ajaran dan karakter islami. Tata tertib tersebut termanifestasi dalam bentuk Buku Poin, yaitu buku yang berisi peraturanperaturan sekolah terhadap peserta didiknya dan disertai poin-poin sebagai sanksi atas jenis pelanggaran tertentu. MAN 1 Tegal termasuk sekolah yang cukup besar dengan sarana dan prasarana yang terbilang lengkap sehingga menunjang pembelajaran siswa. Dibangun di atas lahan seluas 9.200 M2 dengan bangunan gedung permanen dan terbagi ke dalam dua 2 lokal, yaitu bagian selatan dan utara. Bagian selatan merupakan gedung utama sekolah yang berisi kelas-kelas, ruang kepala, TU, dan Mushalla. Sedangkan bagian utara merupakan gedung workshop MAN 1 Tegal, gedung keterampilan Tata Boga dan gedung serba guna (GSG).

Sebagai suatu lembaga pendidikan yang memiliki tujuan, maka MAN 1 Tegal memiliki tujuan jangka panjang yang termaktub dalam Visi dan Misi yang sesuai dengan karakter sekolah berbasis agama Islam. Visi MAN 1 Tegal yaitu "Terwujudnya generasi Islam yang berilmu Ilmiyah, Beramal Islamiyah, Berakhlakul Karimah, Unggul Prestasi, Masa Depan Cerah", sedangkan untuk mewujudkan visi tersebut maka disusunlah misi MAN 1 Tegal yaitu "Menyelenggarakan pendidikan yang berkualitas dalam pencapaian prestasi akademik dan non akademik, mewujudkan pembelajaran dan pembiasaan akhlak mulia dan menjalankan ajaran agama Islam, mewujudkan pembentukan karakter Islami yang mampu mengaktualisasikan diri dalam masyarakat, meningkatkan pengetahuan dan profesionalisme tenaga pendidik dan kependidikan sesuai dengan perkembangan dunia pendidikan, menyelenggarakan tata kelola madrasah yang efektif, efisien, transparan dan akuntabel" (Administrator, 2019).

Salah satu benang merah yang perlu diambil dari visi dan misi MAN 1 Tegal di atas yaitu bahwa MAN 1 Tegal menonjolkan pendidikan karakter selain dari tujuan akademis. Karakter yang diusung tersebut terjelma dalam karakter islami yang disebut dengan Akhlakul Karimah yang berarti akhlak atau etika yang baik. Sehingga harapannya peserta didik MAN 1 Tegal tidak hanya memperoleh ilmu secara kognitif saja, melainkan juga aspek afektif yang sangat penting sebagai bekal untuk mengaplikasikan ilmu yang diperoleh, agar terwujud manusia yang tidak hanya pintar melainkan juga manusia yang berakhlak, benar dan menjunjung tinggi kebenaran (Administrator, 2019).

\section{Bimbingan dan Konseling Berbasis Buku Poin}

Bimbingan dan konseling ialah sebuah kegiatan bimbingan konseling yang dikelola secara terencana dan terarah agar program tersebut dapat terselenggara dengan baik. Karena sebuah kegiatan bimbingan dan konseling tidak mungkin terwujud, terlaksana, dan berhasil ketika tidak mempunyai sebuah sistem pengelolaan yang berkualitas yang artinya dilaksanakan secara jelas, tersistematis serta terarah (Achsan Husairi, 2008).

Adapun bimbingan Islami adalah proses pemberian bantuan terhadap individu agar mampu hidup selaras dengan ketentuan Allah, sehingga dapat mencapai kebahagiaan di dunia dan di akhirat. Dengan demikian dapat diperoleh pemahaman bahwa tidak ada perbedaan dalam proses pemberian bantuan terhadap 


\section{Penerapan Bimbingan Konseling Berbasis Buku Poin dalam Membina Kedisiplinan Peserta Didik di Madrasah Aliyah - Ainur Raman, Begjo Tohari}

DOI: https://doi.org/10.31004/edukatif.v3i5.457

individu, namun dalam bimbingan Islam konsepnya bersumber pada al-Qur'an dan al-Hadist (Musnamar, 1992).

Istilah konseling berasal dari bahasa Inggris yaitu counseling. Sedangkan kata counseling dari kata to counsel yang artinya memberikan nasehat atau memberi anjuran kepada orang lain secara face to face (berhadapan muka satu sama lain) dan juga bisa diartikan advice, yang artinya nasehat atau petuah (Bukhori, 2014)

Dari uraian di atas dapat disimpulkan bahwa istilah bimbingan dan konseling merupakan dua rangkaian kata yang saling berhubungan erat dalam melaksanakan kegiatannya. Besarnya peran konseling di antara keseluruhan bentuk-bentuk pelayanan bimbingan, sampai-sampai konseling dianggap sebagai jantung hatinya bimbingan.

Salah satu petugas bimbingan konseling di MAN 1 Tegal memaparkan bahwa rata-rata pelanggaran yang dilakukan oleh peserta didik adalah merokok, membolos, terlambat masuk sekolah dan tidak disiplin dalam berpakaian, namun pelanggaran dalam skala besar seperti tawuran antar pelajar jarang terjadi bahkan beberapa akhir tahun ini tidak pernah terjadi mengingat mayoritas peserta didik bermukim di pesantren. Sebelum diterapkanya program buku poin jumlah pelanggaran yang dilakukan dapat mencapai $40 \%$, namun setelah diterapkan pelanggaran relatif menurun (Neli, 2020).

Buku Poin di MAN 1 Tegal merupakan sebuah norma sekolah yang mengatur aktivitas peserta didik di sekolah. Penerapan Buku Poin oleh MAN Babakan ini diterapkan guna melancarkan kegiatan belajar mengajar serta mendukung cita-cita sekolah yang tertulis dalam bentuk visi dan misi, mewujudkan tujuan pendidikan nasional agar dapat terwujud dengan efektif, serta menjalankan program sekolah bidang Kesiswaan. Selain itu, penerapan Buku Poin tersebut juga untuk mendukung tujuan pendidikan yang tidak hanya memberikan pengetahuan (kognitif) saja, melainkan juga untuk membentuk sikap (afektif) kepribadian yang baik.

Tahapan penerapan Buku Poin di MAN 1 Tegal dilakukan dengan cara sebagai berikut (Neli, 2020):

\section{1.) Melakukan Rapat Pembentukan Buku Poin}

Sebelum buku poin diterapkan terlebih dahulu dilakukan rapat guna melakukan koordinasi dan perencanaan serta pertimbangan dalam menerapkan buku poin. Rapat dalam rangka membentuk buku poin sebagai tata tertib MAN 1 Tegal ini dilakukan oleh kepala sekolah, wakil kepala sekolah, dan semua guru MAN 1 Tegal termasuk guru Bimbingan Konseling.

\section{2.) Membentuk Tim}

Setelah rapat pembentukan tata tertib dilakukan dan disetujui bersama oleh semua pihak yang terkait, kemudian dibentuk sebuah tim untuk mendukung tata tertib yang diterapkan yang disebut dengan Tim Penyusun Tata Tertib dan Penilaian Kepribadian Peserta Didik MAN 1 Tegal. Tim tersebut terdiri dari guru Bimbingan Konseling, wakil kepala sekolah bidang kesiswaan (wakasis), dan wali kelas. Dalam keputusan hasil rapat Tim Penyusun Tata Tertib dan Penilaian Kepribadian Peserta Didik Madrasah Aliyah Negeri Babakan tersebut diatas, maka tercapai beberapa kesepakatan terkait buku poin.

Sebagai sebuah lembaga kemasyarakatan, MAN 1 Tegal memerlukan sebuah norma agar hubungan antar manusia di dalamnya dapat terlaksana sesuai dengan yang diharapkan. Buku Poin merupakan bentuk norma yang diterapkan sekolah (MAN 1 Tegal) untuk mengatur perilaku peserta didik dengan cara memberikan poin-poin berupa angka atas pelanggaran yang dilakukan dan atau prestasi yang diraih. Poin tersebut memiliki rentang nilai yang berbeda-beda bergantung dengan tingkat dan jenis pelanggaran yang dilakukan peserta didik, semakin tinggi/berat pelanggaran yang dilakukan, maka poin yang diperoleh pun semakin tinggi pula, begitu juga sebaliknya dan berlaku pula pada poin prestasi yang diraih siswa. Bentuk buku poin yang diterapkan di MAN 1 Tegal berbentuk buku berwarna hijau dengan masing-masing buku berlaku untuk satu peserta didik selama berada di MAN 1 Tegal.

Dalam melaksanakan program tersebut meliputi beberapa tahapan-tahapan sebagai berikut (Neli, 2020): 
3366 Penerapan Bimbingan Konseling Berbasis Buku Poin dalam Membina Kedisiplinan Peserta Didik di Madrasah Aliyah - Ainur Raman, Begjo Tohari

DOI: https://doi.org/10.31004/edukatif.v3i5.457

1.) Koordinasi dengan guru mata pelajaran

Koordinasi sangat diperlukan guna memperlancar program yang direncanakan. Koordinasi yang berkaitan dengan Buku Poin ini dilakukan oleh Tim Penyusun Tata Tertib kepada semua guru mata pelajaran. Hal ini dimaksudkan agar guru mata pelajaran ikut serta dalam pengawasan terhadap perilaku peserta didik untuk kemudian memberikan laporan kepada guru Bimbingan Konseling jika terdapat siswa yang melakukan pelanggaran, karena guru mata pelajaran adalah subyek yang diberi tugas untuk mengawasi atau memantau perilaku peserta didik.

2.) Melakukan sosialisasi

Sosialisasi yang berkaitan dengan penerapan Buku Poin ini diberikan pertama; kepada orang tua/wali murid kelas X (sepuluh) sebagai peserta didik baru. Tujuan diberikannya sosialisasi kepada orang tua/wali murid ini diharapkan agar orang tua/wali murid mengetahui tata tertib yang diterapkan sekolah dan ikut mendukung tata tertib tersebut dengan melakukan bimbingan kepada anaknya ketika berada di rumah agar anak tidak memperoleh banyak poin pelanggaran. Karena implikasi dari poin-poin yang diperoleh peserta didik dari pelanggaran yang dilakukan dapat menyebabkan anak di skorsing atau bahkan dikeluarkan dari sekolah. Kedua; sosialisasi diberikan kepada semua peserta didik kelas sepuluh yang juga dilakukan oleh setiap wali kelas dari kelas yang bersangkutan.

\section{3.) Razia Rutin}

Razia yang dimaksud yaitu melakukan operasi pemeriksaan yang dilakukan oleh Tim kepada peserta didik di setiap kelas yang bertujuan untuk menjaga kedisiplinan peserta didik serta menjalankan tata tertib sekolah agar terus berjalan dengan baik. Razia ini dilakukan secara rutin dengan rentang waktu paling lama satu bulan sekali dengan menimbang permintaan dari waka kesiswaan atau wali kelas, dan tentu saja setiap razia yang akan dilakukan direncanakan secara diamdiam agar tidak didengar siswa.

Buku Poin yang diterapkan MAN 1 Tegal memiliki sifat lebih mengikat tiap individu peserta didik, hal ini didasarkan karena Buku Poin yang diterapkan tersebut berbentuk buku yang didalamnya terdapat macammacam peraturan yang harus ditaati oleh peserta didik, poin-poin sebagai ganjaran atas pelanggaran, jenisjenis hukuman dari tiap jumlah poin tertentu, dan lembar catatan pelanggaran siswa. Selain itu, yang membuat Buku bersifat mengikat tiap individu peserta didik yaitu karena masing-masing buku peraturan tersebut berlaku untuk perorangan (individu), jadi setiap siswa memiliki buku poin yang sudah ditandatangani oleh orang tua wali dan siswa yang bersangkutan, sehingga akan ada catatan khusus dari tiap-tiap siswa atas apa yang dilakukannya selama bersekolah di MAN 1 Tegal berkaitan dengan pelanggaran yang dilakukan maupun prestasi yang diraih.

\section{Evaluasi dan hasil dari penerapan buku poin terhadap kedisiplinan peserta didik}

Dalam Permendikbud 111 Tahun 2014 tentang bimbingan dan konseling pada pendidikan dasar dan menengah, bahwa konselor mengevaluasi program bimbingan dan konseling untuk mengetahui keberhasilan layanan dan pengembangan program lebih lanjut. Penerapan program layanan bimbingan dan konseling di Indonesia saat ini menggunakan pola bimbingan dan konseling komprehensif. Komponen program bimbingan dan konseling komprehensif adalah layanan dasar, perencanaan individual, layanan responsif, dan dukungan system (Putri, 2019).

Kedisiplinan hendaknya dipandang sebagai kekuatan positif untuk membentuk dan mengontrol perilaku siswa. Disiplin merupakan kesadaran akan pentingnya ketertiban dan keberaturan dalam kehidupan. Lemahnya tingkat kedisiplinan akan berdampak pada masalah disiplin dalam bentuk pelanggaran terhadap tata tertib sekolah. Bimbingan dan konseling sebagai bagian integral dari pendidikan mempunyai tanggung jawab mengatasi masalah disiplin siswa di sekolah melalui pelayanan bimbingan. Adanya program bimbingan dan konseling diharapkan memiliki solusi untuk menolong siswa mengontrol hidupnya dalam tingkah laku sesuai norma dan bertanggung jawab (Hasibuan, 2014). 


\section{Penerapan Bimbingan Konseling Berbasis Buku Poin dalam Membina Kedisiplinan Peserta Didik di}

Madrasah Aliyah - Ainur Raman, Begjo Tohari

DOI: https://doi.org/10.31004/edukatif.v3i5.457

Kedisiplinan siswa yang di lihat dari penelitian ini yaitu berdasarkan indikator-indikator kedisiplinan sebagai berikut:

1.) Kedisiplinan dalam tata cara berpakaian

a. Berpakaian sesuai dengan ketentuan (atribut, kerudung, kaos kaki, sepatu, baju, celana, mode pakaian, dan ikat pinggang)

b. Memasukkan baju (untuk peserta didik putra)

c. Tidak berpakaian terlalu ketat

d. Peserta didik putra berpeci

Dalam tata cara berpakaian, siswa MAN 1 Tegal secara keseluruhan telah berpakaian sesuai dengan ketentuan. Tetapi masih ada beberapa siswa yang melakukan pelanggaran dengan memakai kaos kaki tidak sesuai seragam (kaos kaki putih untuk seragam putih abu-abu dan batik, kaos kaki hitam untuk seragam pramuka), tidak memasukkan baju, tidak memakai peci, tidak memakai hasduk (untuk seragam pramuka), dan menggunakan ikat pinggang yang tidak sesuai dengan standar yang ditentukan sekolah (Hamzah, 2020).

Sebuah program yang baik, akan terlaksana dengan baik jika manajemennya juga baik, selain juga didukung oleh semua pihak yang terkait. Buku poin yang diterapkan MAN 1 Tegal sebagai tata tertib dan penilaian kepribadian peserta didik merupakan sebuah program sekolah dari wakil kepala sekolah bidang kesiswaan guna mengatur kedisiplinan peserta didik sekaligus sebagai catatan kepribadian peserta didik. Program ini juga merupakan salah satu bentuk upaya untuk mewujudkan Visi dan Misi sekolah khususnya yang berkaitan dengans membentuk peserta didik yang berakhlakul karimah. Oleh karena itu, sebagai sebuah program, agar dapat diterapkan dengan baik maka diperlukan sebuah metode atau cara yang digunakan agar program tersebut dapat berjalan efektif, serta dibutuhkan dukungan dari semua pihak yang terkait demi melancarkan tujuan (Hamzah, 2020).

Dengan penerapan Buku Poin tersebut harapannya siswa tidak hanya pintar secara akademis saja, melainkan juga pandai dalam aspek sosial, mengetahui bagaimana harus berperilaku, dan memiliki sikap kedisiplinan yang baik yang sesuai dengan salah satu tujuan MAN 1 Tegal yaitu membentuk karakter islami dalam bentuk Akhlakul Karimah. Penerapan Buku Poin sebagai tata tertib sekolah juga merupakan bentuk pengendalian sosial (Social control) yang dilakukan oleh pihak sekolah kepada siswanya dengan harapan agar kedepanya siswa dengan adanya penerapan buku poin tersebut dapat berperilaku serta mempunyai kedisiplinan yang baik.

Disiplin adalah kesadaran dan kesediaan seseorang menaati semua peraturan perusahaan dan normanorma sosial yang berlaku (Hasibuan, 2007). Oleh karena itu kedisiplinan merupakan bagian penting dalam pendidikan baik konteks pendidikan formal maupun informal.

Kedisiplinan bukan merupakan sesuatu yang terjadi secara otomatis atau spontan pada diri seseorang melainkan sikap tersebut terbentuk atas dasar beberapa faktor yang mempengaruhinya. Faktor intern, meliputi pembawaan yang menyebabkan orang bersikap disiplin yang merupakan warisan dari keturunannya seperti orang tua atau pihak dari keluarga. Faktor ekstern, Teladan atau modelling adalah contoh perbuatan dan tindakan sehari-hari dari seseorang yang berpengaruh. Keteladanan merupakan salah satu teknik pendidikan yang efektif dan sukses, karena teladan itu menyediakan isyarat-isyarat non verbal sebagai contoh yang jelas untuk ditiru. Dalam Pendidikan mendisiplinkan peserta didik harus di awali dengan pripadi pendidik yang di siplin (Hasan \& Rusydiana, 2018)

Selain faktor-faktor yang mempengaruhi kedisiplinan ada juga usaha dalam meningkatkan kedisiplinan peserta didik yang diantaranya yaitu dengan melakukan pembiasaan, ketika anak dibiasakan melakukan sesuatu dengan baik, tertib, dan teratur, misalnya, berpakaian rapi, keluar masuk kelas harus hormat pada guru, harus memberi salam dan lain sebagainya.

Jadi apa yang dikatakan oleh Hasibuan sesuai dengan apa yang terjadi di MAN 1 Tegal, karena buku poin (tata tertib) merupakan aturan yang memberikan petunjuk dan menjadi pedoman seseorang dalam 


\section{Penerapan Bimbingan Konseling Berbasis Buku Poin dalam Membina Kedisiplinan Peserta Didik di Madrasah Aliyah - Ainur Raman, Begjo Tohari}

DOI: https://doi.org/10.31004/edukatif.v3i5.457

masyarakat untuk berperilaku guna melancarkan kegiatan belajar mengajar serta mendukung cita-cita sekolah yang tertulis dalam bentuk visi dan misi, mewujudkan tujuan pendidikan nasional agar dapat terwujud dengan efektif, serta menjalankan program sekolah.

Pelanggaran-pelanggaran dalam tata cara berpakaian ini lebih kerap dilakukan oleh peserta didik putra. Sedangkan untuk peserta didik putri, hampir secara keseluruhan telah berpakaian sesuai dengan ketentuan. Dari pelanggaran-pelanggaran yang dilakukan, dari hasil wawancara yang dilakukan ternyata siswa memiliki alasan-alasan yang berbeda-beda, ada yang dikarenakan hal-hal tertentu hingga menyebabkan siswa tidak bisa beratribut sesuai dengan ketentuan, tetapi ada pula yang dikarenakan tidak ada guru yang melihat. YN siswa kelas XI IPS 2, saat penelitian dilakukan YN memakai kaos kaki hitam sedangkan seragamnya adalah putih abu-abu, alasan memakai kaos kaki hitam dikatakan yaitu karena gugup saat hendak berangkat sekolah, tetapi biasanya memakai kaos kaki putih. Sedangkan ZS siswa kelas XI IPA 2, juga memakai kaos kaki hitam padahal seragamnya adalah putih abu-abu, alasan memakai kaos kaki hitam tersebut dikatakan ZS karena berasal dari pondok, jadi sering terjadi kehilangan kaos kaki dan terpaksa memakai kaos kaki hitam. Selain itu, ZS juga menambahkan bahwa guru tidak terlalu memperhatikan perihal kaos kaki yang dipakai siswanya, hanya guru-guru tertentu yang memperhatikan. Pernyataan hasil ZS tersebut menunjukkan bahwa siswa melakukan pelanggaran selain dikarenakan alasan yang syar'i juga dikarenakan kurangnya pengawasan dari guru.

\section{2.) Disiplin Waktu}

a. Tidak terlambat masuk madrasah lebih dari 10 menit

b. Tidak terlambat masuk kelas setelah pergantian jam pelajaran lebih dari 10 menit

Bel tanda bunyi dimulainya pelajaran pertama, dimulai tepat pada jam 07:00 WIB, tetapi pada jam tersebut gerbang masih belum ditutup karena memang ada toleransi waktu selama 10 menit dan selama itu masih terdapat siswa yang baru berangkat. Tetapi ketika gerbang sekolah telah ditutup, masih terdapat beberapa siswa yang baru berangkat sehingga terpaksa masuk ke ruang BK untuk diberi pengarahan dan dilakukan pencatatan. Selama berada di ruang BK, siswa yang terlambat kemudian memberikan alasan keterlambatannya dan menulisnya di surat keterlambatan siswa sebagai syarat dapat masuk ke kelas mengikuti pelajaran. Sedangkan guru BK memberikan beberapa pengarahan agar keterlambatan siswa tersebut tidak terjadi lagi dan mendata siswa yang terlambat ke dalam buku Volume Keterlambatan Siswa dan memasukkannya ke dalam Buku Poin.

\section{KESIMPULAN}

Penerapan Buku Poin di MAN Babakan merupakan bagian dari usaha untuk mewujudkan visi dan misi MAN Babakan. Dengan adanya buku poin yang mulai diterapkan pada tahun 2007 ini diharapkan kedisiplinan peserta didik yang sesuai dengan karakter islami MAN Babakan dapat terwujud. Karena alasan utama penerapan buku poin di MAN Babakan yaitu untuk memperbaiki masalah kedisiplinan peserta didik. Selain itu, alasan lain diterapkannya buku poin yaitu karena MAN Babakan menginginkan adanya pencatatan kepribadian peserta didik, sebagai dasar untuk menentukan kenaikan kelas dan atau keberhasilan siswa.

Buku Poin sebagai tata tertib MAN Babakan memiliki sifat yang lebih mengikat tiap individu peserta didik, karena berbentuk buku dan setiap peserta didik memiliki buku poin sebagai catatan kepribadiannya. Selain itu, buku poin sebagai social control memiliki sifat preventif sebagai pencegah terjadinya perilaku menyimpang dan sifat represif sebagai sanksi atas perilaku menyimpang yang dilakukan peserta didik. 
3369 Penerapan Bimbingan Konseling Berbasis Buku Poin dalam Membina Kedisiplinan Peserta Didik di Madrasah Aliyah - Ainur Raman, Begjo Tohari

DOI: https://doi.org/10.31004/edukatif.v3i5.457

\section{DAFTAR PUSTAKA}

Achsan Husairi. (2008). Manajemen Pelayanan Bimbingan Dan Konseling Di Sekolah. Bogor: PT Arya Duta.

Adianto, S., Kusumarini, E., \& Nurhayati. (2020). Analisis Manajemen Pendekatan Kelas Dalam Meningkatkan Kedisiplinan Peserta Didik SDN 002 Sungai Pinang. Inteligensi : Jurnal Ilmu Pendidikan, $3(2), 32-40$.

Administrator. (2019). Dokumentasi Profil MAN 1 Tegal. 17 Maret. Https://Man1tegal.Sch.Id/

Bukhori, B. (2014). Dakwah Melalui Bimbingan Dan Konseling Islam. KONSELING RELIGI: Jurnal Bimbingan Konseling Islam, 5(1), 1-18.

Desiyanto, J., Pantiwati, Y., \& Tinus, A. (2018). Implementasi Kebijakan Sistem Poin Pelanggaran Dalam Upaya Membentuk Siswa Berkarakter SMA Islam Yakin Tutur Pasuruan. Jurnal Kebijakan Dan Pengembangan Pendidikan, 6(1), 86-100.

Diana, A., \& Pambudi, A. (2013). Rancang Bangun Sistem Informasi Kredit Poin Siswa Dengan Metodologi Berorientasi Obyek Studi Kasus : SMK Negeri 18 Jakarta. Jurnal Ticom, 2(1), 1-6.

Fitriawati, C., Sulistiyorini, \& Parijo. (2017). Penerapan Sistem Poin Dalam Menanggulangi Siswa Yang Melanggar Aturan Di SMA N 2 Pontianak. Jurnal Pendidikan Dan Pembelajaran Khatulistiwa, 4(6), 1 11.

Hadianti, L. S. (2008). Pengaruh Pelaksanaan Tata Tertib Sekolah Terhadap Kedisiplinan Belajar Siswa (Penelitian Deskriptif Analisis Di SDN Sukakarya II Kecamatan Samarang Kabupaten Garut). Jurnal Pendidikan Universitas Garut, 02(1), 1-8.

Hamzah. (2020). Wawancara (Waka Kesiswaan MAN 1 Tegal).

Hasan, M. S., \& Rusydiana, H. (2018). Penerapan Sanksi Edukatif Dalam Peningkatan Kedisiplinan Peserta Didik Di MTS Semesta Kedungmaling Sooko Mojokerto. CENDEKIA: Jurnal Studi Keislaman, 4(2), 152-178. Https://Doi.Org/10.37348/Cendekia.V4i2.63

Hasibuan, M. S. P. (2007). Manajemen Sumber Daya Manusia. Jakarta: Bumi Aksara.

Hasibuan, M. S. P. (2014). Manajemen Sumber Daya Manusia. Bandung: PT. Bumi Aksara. Https://Doi.Org/10.35673/Ajmpi.V9i2.429

Hasibuan, M. S. P. (2015). Manajemen, Dasar, Pengertian, Dan Masalah. Makassar: PT Bumi Aksara.

Hidayati, Suhardi, Irfan, D., Ambiyar, \& Melyanti, R. (2020). Web-Based Student Violation Information System Uing Rapid Application Development. Journal Of Information Technology And Computer Science (INTECOMS), 3(2), 234-242.

Musnamar, T. (1992). Dasar-Dasar Konseptual Bimbingan Dan Konseling Islami. Jakarta: UII Press.

Muthoharoh, V., \& Sakti, N. C. (2021). Media Pembelajaran Interaktif Menggunakan Adobe Flash CS6 Untuk Pembelajaran IPS Siswa Sekolah Menengah Atas. Edukatif: Jurnal Ilmu Pendidikan, 3(2), 364-375.

Nasution, S. (2010). Sosiologi Pendidikan. Jakarta : Bumi Aksara.

Neli. (2020). Wawancara (Kepala BK MAN 1 Tegal).

Putri, A. E. (2019). Evaluasi Program Bimbingan Dan Konseling: Sebuah Studi Pustaka. JBKI (Jurnal Bimbingan Konseling Indonesia), 4(2), 39-42. Https://Doi.Org/10.26737/Jbki.V4i2.890

Rasdiyanah, A. (2005). Pendidikan Agama Islam. Bandung: Lubuk Agung.

Rasimin, Yusra, A., \& Wahyuni, H. (2021). Penerapan Bimbingan Belajar Berbasis Prinsip-Prinsip Belajar Dalam Islam Untuk Meningkatkan Etika Belajar Siswa. Edukatif: Jurnal Ilmu Pendidikan, 3(2), 321332.

Sugiyono. (2011). Metodologi Penelitian Kuantitatif Kualitatif Dan $R \&$ D. Bandung: Alpabeta. 
3370 Penerapan Bimbingan Konseling Berbasis Buku Poin dalam Membina Kedisiplinan Peserta Didik di Madrasah Aliyah - Ainur Raman, Begjo Tohari

DOI: https://doi.org/10.31004/edukatif.v3i5.457

Suhaeni, H. E. (2018). Pendidikan Dan Pelapisan Sosial (Social Stratification). Islamika:Jurnal Agama, Pendidkan Dan Sosial Budaya, 12(1), 45-56.

Sukmadinata, N. S. (2011). Metode Penelitian Pendidikan; Penelitian Memberikan Deskripsi, Eksplanasi, Prediksi, Inovasi, Dan Juga Dasar-Dasar Teoritis Bagi Pengembangan Pendidikan. Bandung: UPI Dan PT. Remaja Rosdakarya.

Supiana, Hermawan, A. H., \& Wahyuni, A. (2019). Manajemen Peningkatan Karakter Disiplin Peserta Didik Melalui Kegiatan Ekstrakurikuler. Jurnal Islamic Education Manajemen, 4(2), 193-208. 